Jurnal MAKSIPRENEUR, Vol. I, No. 2, 2012, hal. 17-32

\title{
PENGARUH KEMUDAHAN PENGGUNAAN DAN MANFAAT YANG DIRASAKAN TERHADAP SIKAP DAN NIAT PEMBELIAN ONLINE (STUDI PADA PEMBELIAN BATIK DI JAWA TIMUR)
}

\author{
R. Andi Sularso \\ Fakultas Ekonomi Universitas Jember
}

\begin{abstract}
The design of this study are included in the confirmatory research and research as well as explanatory. Analysis technique used is to use the Structural Equation Modeling (SEM).. Data retrieval techniques using purposive sampling method with the number of respondents 140 respondents. The results showed that: (1) Ease of use online shopping perceived significantly influence consumers 'attitude towards online purchases batik in East Java, (2) the perceived benefits of online shopping significantly influence consumers' attitude towards online purchases batik in East Java, (3) Ease of use online shopping perceived significant impact on repeat purchase intention online Batik in East Java, (4) the perceived benefits of online shopping does not significantly influence online purchase intentions in batik in East Java, (5) the attitude of influential consumers significant impact on repeat purchase intention online batik in East Java.
\end{abstract}

Key Words: Technology Acceptance Model (TAM), Online Purchasing

\section{PENDAHULUAN}

Technology Acceptance Model (TAM), banyak digunakan untuk memprediksi, perilaku keputusan pembelian secara online. TAM adalah model yang pertama kali diperkenalkan oleh Davis pada tahun 1986, untuk menjelaskan penerimaan teknologi yang akan digunakan. Tujuan utama TAM adalah untuk menjelaskan faktor yang mempengaruhi penerimaan teknologi dan informasi dengan jangkauan luas dari teknologi informasi pengguna. Pada penelitian ini penerimaan teknologi adalah penerimaan teknologi internet yang digunakan untuk pembelian online. Tinjauan studi empiris menunjukkan bahwa Theory Reasoned Action ( Fishbein dan Ajzen, 1975, dan TAM dari Davis, 1989), adalah teori yang menjelaskan perilaku pembelian online. TAM digunakan untuk meramalkan perilaku niat 
menggunakan teknologi informasi. Model TAM menjelaskan sikap yang mengarah pada penggunaan teknologi baru dipengaruhi oleh manfaat yang dirasakan (Perceived Usefullness, disingkat PU) dan kemudahan penggunaan (Perceived Ease of Use disingkat PEoU). Perusahaan yang melakukan penjualan secara online akan merancang website-nya dengan menarik mulai dari produk yang ditawarkan, ketersediaan produk, cara pembayaran, sehingga konsumen tertarik untuk melakukan pembelian.

Pada model TAM niat pembelian dapat dipengaruhi oleh sikap, manfaat yang dirasakan (PU) dan kemudahan penggunaan (PEoU). Mowen and Minor, (2002) menjelaskan semua kegiatan pemasaran yang berhubungan dengan sikap konsumen. Sikap merupakan ekspresi perasaan mencerminkan perasaan seseorang senang atau tidak senang, suka atau tidak suka, setuju atau tidak setuju terhadap suatu objek, sehingga niat konsumen untuk melakukan pembelian online dipengaruhi oleh afeksi konsumen pada proses pembelian online.

Kemudahan penggunaan yang dirasakan konsumen (PEoU) berpengaruh langsung terhadap sikap dan niat. Pengaruh langsung kemudahan penggunaan terhadap sikap adalah semakin konsumen merasa mudah menggunakan pembelian online, prosedur pembelian mudah, prosedur jelas, maka orang semakin bersikap positif terhadap online. Karena semakin mudah proses penggunaan teknologi untuk pembelian online; prosesnya mudah dipahami, mudah digunakan, prosedurnya jelas, maka konsumen akan semakin berniat untuk melakukan pembelian dengan cara online, dengan persepsi bahwa berpembelian melalui online akan bebas dari kesulitan atau memudahkan

Penggunaan internet tidak mengenal tempat atau lokasi, di manapun konsumen bisa melakukan transaksi melalui online, selama sarananya tersedia. Konsumen sudah semakin mudah menemukan tempat yang menyediakan sarana untuk berinternet. Oleh karena itu penelitian ini akan dilakukan di Jawa Timur dengan mengambil sampel pada pelanggan yang melakukan pembelian batik secara online. Alasan studi pembelian batik, karena batik merupakan warisan budaya Indonesia yang disyahkan oleh UNESCO pada tanggal 2 Oktober 2009 dan dicanangkan sebagai hari batik, maka dengan penelitian ini sebagai bentuk keikutsertaan partisipasi melestarikan dan mencintai batik.

\section{RUMUSAN MASALAH}

Berdasarkan latar belakang di atas, maka rumusan masalah dalam penelitian ini adalah sebagai berikut: (a) Apakah kemudahan penggunaan pembelian online yang dirasakan berpengaruh signifikan terhadap sikap konsumen pada pembelian online batik di Jawa Timur? ; (b) Apakah manfaat pembelian online yang dirasakan berpengaruh signifikan terhadap 
sikap konsumen pada pembelian online batik di Jawa Timur ? ; (c) Apakah kemudahan penggunaan pembelian online yang dirasakan berpengaruh signifikan terhadap niat pembelian ulang online batik di Jawa Timur?; (d) Apakah manfaat pembelian online yang dirasakan berpengaruh signifikan terhadap niat pembelian ulang online batik di Jawa Timur? ; (e) Apakah sikap konsumen berpengaruh signifikan terhadap niat pembelian ulang online batik di Jawa Timur?

\section{TINJAUAN PUSTAKA}

\subsection{E-Marketing}

E-Marketing is the marketing side of E-Commerce, it consists of company efforts to communicate about, promote and sell products and services over the internet (Kotler dan Keller, 2012). Kata lain dari e-marketing adalah ECommerce, merupakan kegiatan pemasaran perusahaan untuk mengkomunikasikan dan menjual barang dan jasa melalui internet.

Penggunaan internet untuk aktivitas transaksi bisnis dikenal dengan istilah Elektronic Commerce (e-commerce). Karakteristik e-commerce terdiri atas terjadinya transaksi antara dua belah pihak; adanya pertukaran barang dan jasa, atau informasi; dan internet sebagai medium utama dalam proses transaksi. Perusahaan memanfaatkan kemudaham e-commerce untuk seluruh proses dari pemasaran, penjualan, pengiriman, pelayanan, dan pembayaran untuk berbagai produk dan jasa yang diperjualbelikan dalam pasar global berjaringan para pelanggan, dengan dukungan dari jaringan para mitra bisnis di seluruh dunia (O'Brien, 2005). Oleh karena itu, mengembangkan kemampuan e-commerce menjadi pilihan penting yang harus dipertimbangkan oleh kebanyakan perusahaan saat ini (O'Brien, 2005).

\subsection{Technology Acceptance Model (TAM)}

TAM adalah model yang disusun oleh Davis (1989) untuk menjelaskan penerimaan teknologi yang akan digunakan oleh pengguna teknologi seperti tergambarkan dalam gambar 1 berikut. Menurut Davis perilaku menggunakan teknologi informasi (IT) diawali oleh adanya manfaat yang dirasakan (perceived usefulness) dan kemudahan menggunakan yang dirasakan pada IT (perceived ease of use). Dalam studi selanjutnya, Davis et al., 1989 telah mengembangkan dua konstruksi asli untuk, manfaat dan kemudahan penggunaan, yang merupakan penentu utama untuk menjelaskan adopsi teknologi.

Model TAM yang diusulkan oleh Davis (1989), sikap yang mengarah pada penggunaan teknologi baru yang dipengaruhi oleh manfaat yang dirasakan (Perceived Usefulness) dan kemudahan penggunaan yang dirasakan (Perceived Ease of Use). Kerangka teoritis pada penelitian ini 
didasarkan pada teori-teori dari model TAM. Penelitian menggunakan TAM untuk memprediksi adopsi dan penggunaan channel online, karena lingkungan e-commerce adalah pendorong teknologi yang kuat. Temuan dari penelitian yang berhubungan dengan TAM menyediakan pengertian yang mendalam ke faktor determinan adopsi dan penggunaan e-Commerce. Model TAM menjelaskan bahwa (PU) dan (PEoU) suatu teknologi mempengaruhi sikap pemakai terhadap penggunaan teknologi, yang selanjutnya mempengaruhi niat perilaku, yang akhirnya menemukan adopsi dan penggunaan (Davis 1989). Manfaat yang dirasakan (PU) memberi pengertian tingkat kepercayaan menggunakan sistem akan meningkatkan kinerjanya, sedangkan kemudahan penggunaan yang dirasakan (PEoU) mengacu pada tingkat kepercayaan menggunakan sistem akan bebas dari usaha keras (Davis 1989). PU mengacu pada persepsi hasil dari pengalaman, $P E o U$ mengacu pada persepsi mengenai proses yang mendorong ke hasil ( Childers et al.). Jika konsumen berpersepsi bahwa penggunaan internet lebih mudah dan bermanfaat, maka akan meningkatkan kesenangan mereka untuk mengadopsi dan menggunakannya. $P E O U$ juga berpengaruh secara positif pada $P U$, seperti system lebih mudah untuk digunakan, dapat lebih bermanfaat (Venkatesh, 20oo). Dalam pengembangan TAM, Davis et al, (1989) menemukan bukti bahwa sikap memprediksi niat.

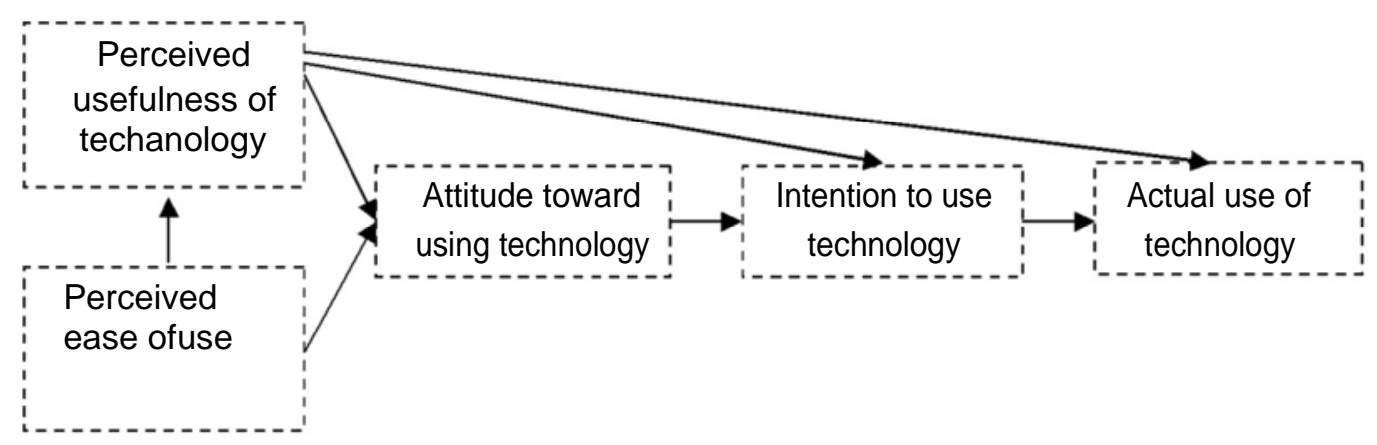

Sumber: Davis, 1989

Gambar 1. Technology Acceptance Model (TAM)

Beberapa studi yang menguji TAM pada online (Lederer et al., 200o; Childers et al., 2001; Gefen et al., 2003). Studi mereka mengkonfirmasikan bahwa keyakinan pengguna PEOU dan PU, merupakan faktor utama untuk penerimaan dan adopsi e-commerce. Childers et al. (2001 ), menemukan bahwa masing-masing variabel mempengaruhi secara positif sikap konsumen terhadap pembelian online. Davis et al., (1989) menyatakan bahwa tujuan utama TAM, adalah untuk menjelaskan faktor-faktor yang mempengaruhi penerimaan teknologi informasi. Jangkauan teknologi informasi dan pengguna yang luas dalam TAM penggunaannya sistem 
ditentukan oleh perilaku niat dalam menggunakan, yang selanjutnya ditentukan bersama dengan sikap terhadap $P U$ dan PEoU. PEoU merupakan suatu determinan langsung atas $P U$ dan determinan tidak langsung atas sikap.

\section{METODE PENELITIAN}

\subsection{Rancangan Penelitian}

Penelitian ini dirancang sebagai penelitian eksplanatori, karena bertujuan untuk menjelaskan pengaruh hubungan sebab akibat di antara variabel-variabel, di dalam permasalahan penelitian yang telah diidentifikasi secara jelas. Penelitian ini bertujuan untuk menjelaskan hubungan dan pengaruh antar variabel, yaitu antara Perceived Ease Of Use, Perceived Usefulness, terhadap Attitude toward online. Perceived Ease Of Use, Perceived Usefulness, terhadap Repurchase intention online. Attitude toward online terhadap Repurchase intention online pada pembelian batik di Jawa Timur.

\subsection{Populasi dan Sampel}

Target populasi dalam penelitian ini adalah pelanggan batik di Jawa Timur yang melakukan pembelian melalui online lebih dari 1 kali pembelian. Teknik pengambilan sampel yang digunakan dalam penelitian ini adalah cluster proporsional sampling. Sampel yang diambil berdasarkan kelompok populasi konsumen pembeli batik online di Jawa Timur.

Tabel 1.

\begin{tabular}{|l|c|c|}
\multicolumn{3}{|c|}{ Alokasi Jumlah Sampel } \\
\hline Wilayah & Populasi & $\begin{array}{c}\text { Sampel } \\
\text { (dibulatkan) }\end{array}$ \\
\hline Surabaya & 81 & 48 \\
\hline Malang & 57 & 34 \\
\hline Sidoarjo & 35 & 21 \\
\hline Pamekasan & 62 & 37 \\
\hline Jumlah & 235 & 140 \\
\hline
\end{tabular}

Sumber:Hasil Analisis

Besar sampel yang diambil dalam penelitian ini sebanyak 140 orang responden, dengan kriteria sebagai berikut: (a) Pembeli batik di Jawa Timur yang berasal dari daerah Surabaya, Malang, Sidoarjo dan Pamekasan; (b) Konsumen batik yang telah menjadi pelanggan atau melakukan pembelian lebih dari 1 kali pembelian. Ferdinand (2006:51) menyatakan, " ukuran sampel tergantung pada jumlah indikator yang digunakan dalam seluruh variabel laten, jumlah sampel adalah sama dengan jumlah indikator yang 
digunakan dikalikan 5 sampai dengan 10.” Mengacu pendapat Ferdinand tersebut, maka jumlah sampel dalam penelitian ini ditetapkan sebesar 140 responden yang diperoleh dari jumlah seluruh indikator yang digunakan dalam penelitian dikalikan dengan $10(14 \times 10=140)$. Alokasi jumlah sampel bisa dilihat pada tabel di atas.

\subsection{Metode Pengumpulan Data}

Pengumpulan data dilakukan secara langsung pada pembeli batik di Jawa Timur yang pemasarannya melalui online. Adapun jenis data dan prosedur pengumpulannya dalam penelitian ini diperoleh dari: (a) Wawancara, yaitu mengadakan tanya jawab secara langsung dengan pihak pihak yang terkait; (b) Kuesioner, daftar pertanyaan tertulis yang telah dirumuskan sebelumnya yang dijawab responden.

\subsection{Teknik Analisis Data}

Penelitian ini bertujuan untuk membuktikan dan menganalisis pengaruh variabel eksogen terhadap variabel endogen. Variabel eksogen: Perceived Ease Of Use (XI), Perceived Usefulness (X2), variabel endogen intervening: Attitude toward online ( $\left.\mathrm{Y}_{1}\right)$ dan variable endogen tergantung adalah Repurchase intention online (Y2). Teknik analisis menggunakan Structural Equation Modelling (SEM) dengan menggunakan paket program Analysis of Moment Structure (AMOS).

\section{HASIL PENELITIAN}

\subsection{Analisis Structural Equation Modelling (SEM)}

Hasil pengujian dengan program AMOS memberikan hasil model SEM seperti terlihat pada gambar 2 berikut yang menunjukakan pengaruh Perceived Ease of Use dan Perceived Usefulness terhadap Sikap Konsumen dan Niat Pembelian Ulang online. 


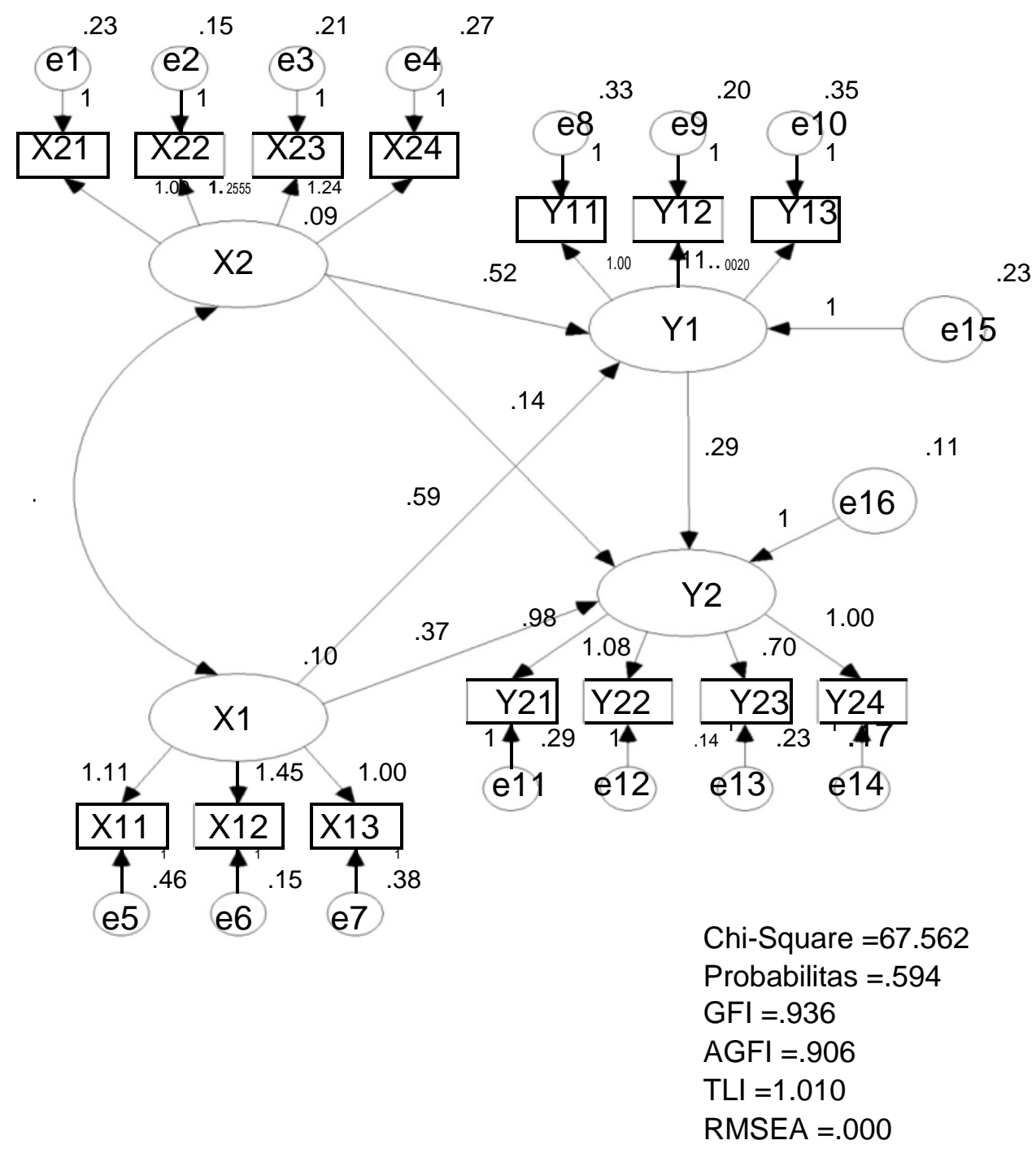

Gambar 2. Hasil Analisis SEM

a. Uji Kesesuaian Model (Goodness of Fit Test)

Pengujian pada model SEM bertujuan untuk melihat kesesuaian model, hasil pengujian kesesuaian model dalam studi ini disajikan pada tabel 2. Berdasakan tabel 2 tersebut dapat diketahui bahwa dari delapan kriteria yang digunakan untuk menilai layak/tidaknya suatu model telah terpenuhi. Sehingga dapat dinyatakan bahwa model dapat diterima yang berarti ada kesesuaian model dengan data. 
Tabel 2. Indeks Kesesuaian SEM

\begin{tabular}{|c|c|c|c|}
\hline Kriteria & Nilai Cut Off & Hasil Pengujian & Keterangan \\
\hline Chi Square & $\begin{array}{l}\text { Diharapkan lebih } \\
\text { kecil dari } \mathrm{X}^{2} \text { pada } \\
\mathrm{df}=71 \text { yaitu } \\
114,82\end{array}$ & 67,652 & Baik \\
\hline $\begin{array}{l}\text { Sig. } \\
\text { Probability }\end{array}$ & $\geq 0,05$ & 0,594 & Baik \\
\hline RMSEA & $\leq 0,08$ & 0,000 & Baik \\
\hline GFI & $\geq 0,90$ & 0,936 & Baik \\
\hline AGFI & $\geq 0,90$ & 0,906 & Baik \\
\hline CMIN/DF & $\leq 2$ atau 3 & 0,952 & Baik \\
\hline TLI & $\geq 0,95$ & 1,010 & Baik \\
\hline CFI & $\geq 0,95$ & 1,000 & Baik \\
\hline
\end{tabular}

Sumber: Hasil nalisis

b. Uji Kausalitas

Setelah dilakukan pengujian kesesuian model, maka langkah selanjutnya adalah menguji kausalitas yang dikembangkan dalam penelitian tersebut. Dari model yang sesuai, maka dapat diinterpretasikan masingmasing koefisien jalur. Pengujian koefisien jalur secara rinci disajikan dalam tabel 3 berikut.

Tabel 3. Hasil Uji Kausalitas

\begin{tabular}{lllcrrrl}
\hline & & & Estimate & S.E. & C.R. & \multicolumn{1}{c}{ P } & Label \\
\hline $\mathrm{Y}_{1}$ & $<---$ & $\mathrm{X}_{2}$ & 0,523 & 0,213 & 2,457 & 0,014 Sig. \\
$\mathrm{Y}_{1}$ & $<---$ & $\mathrm{X}_{1}$ & 0,589 & 0,245 & $\mathbf{2 , 4 0 7}$ & 0,016 Sig. \\
$\mathrm{Y}_{2}$ & $<---$ & $\mathrm{X}_{2}$ & 0,143 & 0,152 & 0,940 & 0,347 Tidak Sig. \\
$\mathrm{Y}_{2}$ & $<---$ & $\mathrm{Y}_{1}$ & 0,293 & 0,099 & $\mathbf{2 , 9 7 0}$ & 0,003 Sig. \\
$\mathrm{Y}_{2}$ & $<---$ & $\mathrm{X}_{1}$ & 0,368 & 0,185 & 1,988 & 0,047 & Sig. \\
\hline
\end{tabular}

Sumber: Hasil nalisis

Berdasarkan Tabel 3 tersebut dapat dinyatakan bahwa hasil pengujian koefisien jalur untuk pengaruh Perceived Ease of Use $\left(\mathrm{X}_{1}\right)$ terhadap Sikap Konsumen $\left(\mathrm{Y}_{1}\right)$ memiliki jalur positif sebesar 0,589 dengan C.R sebesar 2,407 dan probabilitas (p) sebesar o,016 yang berarti bahwa Perceived Ease of Use $\left(\mathrm{X}_{1}\right)$ berpengaruh signifikan terhadap Sikap Konsumen $\left(\mathrm{Y}_{1}\right)$.

Hasil pengujian koefisien jalur untuk pengaruh Perceived Usefulness $\left(\mathrm{X}_{2}\right)$ 
terhadap Sikap Konsumen $\left(\mathrm{Y}_{1}\right)$ memiliki jalur positif sebesar o,523 dengan C.R sebesar 2,457 dan probabilitas (p) sebesar o,014 yang berarti bahwa Perceived Ease of Use $\left(\mathrm{X}_{1}\right)$ berpengaruh signifikan terhadap Sikap Konsumen $\left(\mathrm{Y}_{1}\right)$. Hasil pengujian koefisien jalur untuk pengaruh Perceived Ease of Use $\left(\mathrm{X}_{1}\right)$ terhadap Niat Pembelian Ulang online $\left(\mathrm{Y}_{2}\right)$ memiliki jalur positif sebesar 0,368 dengan C.R sebesar 1,988 dan probabilitas (p) sebesar o,047 yang berarti bahwa Perceived Ease of Use $\left(\mathrm{X}_{1}\right)$ berpengaruh signifikan terhadap Niat Pembelian Ulang online $\left(\mathrm{Y}_{2}\right)$. Hasil pengujian koefisien jalur untuk pengaruh Perceived Usefulness $\left(\mathrm{X}_{2}\right)$ terhadap Niat Pembelian Ulang online $\left(\mathrm{Y}_{2}\right)$ memiliki jalur positif sebesar o,143 dengan C.R sebesar 0,940 dan probabilitas (p) sebesar 0,347 yang berarti bahwa Perceived Usfulness $\left(\mathrm{X}_{2}\right)$ berpengaruh tidak signifikan terhadap Niat Pembelian Ulang online $\left(\mathrm{Y}_{2}\right)$. Hasil pengujian koefisien jalur untuk pengaruh Sikap Konsumen $\left(\mathrm{Y}_{1}\right)$ terhadap Niat Pembelian Ulang online $\left(\mathrm{Y}_{2}\right)$ memiliki jalur positif sebesar o,293 dengan C.R sebesar 2,970 dan probabilitas (p) sebesar o,003 yang berarti bahwa Sikap Konsumen $\left(\mathrm{Y}_{1}\right)$ berpengaruh signifikan terhadap Niat Pembelian Ulang online $\left(\mathrm{Y}_{2}\right)$.

\subsection{Pengaruh Antar Variabel}

a. Pengaruh Langsung Antar Variabel

Hubungan pengaruh langsung terjadi antara variabel laten eksogen Perceived Ease of Use dan Perceived Usefulness dengan variabel endogen intervening Sikap Konsumen dan variabel laten endogen terikat yaitu Niat Pembelian Ulang online . Ringkasan mengenai pengaruh langsung dari variabel tersebut dapat dilihat pada tabel 4 berikut.

Tabel 4. Pengaruh Langsung Variabel

\begin{tabular}{|c|l|c|c|}
\hline \multirow{2}{*}{$\begin{array}{c}\text { Pengaruh } \\
\text { Langsung }\end{array}$} & \multicolumn{3}{|c|}{ Variabel Endogen } \\
\cline { 2 - 4 } & $\begin{array}{l}\text { Perceived Ease } \\
\text { of Use }\end{array}$ & Sikap Konsumen & Niat Pembelian Ulang \\
\cline { 2 - 4 } Variabel \\
Eksogen & $\begin{array}{l}\text { Perceived } \\
\text { Usefulness }\end{array}$ & 0,330 & 0,273 \\
\cline { 2 - 4 } & Sikap Konsumen & 0,000 & 0,105 \\
\hline
\end{tabular}

Sumber: Hasil Analisis

Berdasarkan tabel 4 tersebut dapat diketahui bahwa pengaruh langsung Perceived Ease of Use terhadap sikap konsumen sebesar 0,330 dengan arah positif, Perceived Usefulness terhadap Sikap Konsumen sebesar 0,291 dengan arah positif, Perceived Ease of Use terhadap niat pembelian ulang online sebesar 0,273 dengan arah positif, Perceived Usefulness terhadap niat pembelian ulang online sebesar 0,105 dengan arah positif, 
dan sikap konsumen terhadap niat pembelian ulang online sebesar 0,388 dengan arah positif.

Berdasarkan pengujian tersebut dapat dinyatakan bahwa Perceived Ease of Use mempunyai efek langsung terbesar terhadap sikap konsumen, sedangkan sikap konsumen mempunyai efek langsung terbesar terhadap niat pembelian ulang online.

Hasil pengujian langsung terhadap keempat variabel yaitu perceived ease of use, sikap konsumen, niat pembelian ulang menunjukkan bahwa perceived ease of use mempunyai efek langsung terbesar terhadap niat pembelian ulang online. Hal ini berarti variabel laten PeoU memberikan kontribusi yang besar dalam mempengaruhi niat pembelian ulang online. Sedangkan PU mempunyai pengaruh langsung terkecil terhadap niat Pembelian Ulang online. Hal ini berarti variabel laten PU tidak mempunyai pengaruh yang besar terhadap pembelian online.

b. Pengaruh Tidak Langsung Antar Variabel

Pengaruh tidak langsung terjadi antara variabel laten eksogen Perceived Ease of Use dan Perceived Usefulness dengan variabel endogen intervening Sikap Konsumen dan variabel laten endogen terikat yaitu niat pembelian ulang online. Ringkasan mengenai pengaruh langsung dari variabel tersebut dapat dilihat pada tabel 5 berikut.

Tabel 5. Pengaruh Tidak Langsung Antar Variabel

\begin{tabular}{|c|c|c|c|}
\hline \multirow{2}{*}{$\begin{array}{l}\text { Pengaruh } \\
\text { Tdk. } \\
\text { Langsung }\end{array}$} & \multicolumn{3}{|c|}{ Variabel Endogen } \\
\hline & & Sikap Konsumen & Niat Pembelian Ulang \\
\hline \multirow{3}{*}{$\begin{array}{l}\text { Variabel } \\
\text { Eksogen }\end{array}$} & $\begin{array}{c}\text { Perceived Ease } \\
\text { of Use }\end{array}$ & 0,000 & 0,128 \\
\hline & $\begin{array}{l}\text { Perceived } \\
\text { Usefulness }\end{array}$ & 0,000 & 0,113 \\
\hline & $\begin{array}{c}\text { Sikap } \\
\text { Konsumen }\end{array}$ & 0,000 & 0,000 \\
\hline
\end{tabular}

Sumber: Hasil Analisis

Berdasarkan tabel 5 tersebut dapat diketahui bahwa pengaruh tidak langsung Perceived Ease of Use terhadap niat pembelian ulang online sebesar 0,128 dengan arah positif dan Perceived Usefulness terhadap niat pembelian ulang online sebesar o,113 dengan arah positif.

Hal pengujian pengaruh langsung pada tabel 4 menunjukkan bahwa besarnya pengaruh langsung PeoU terhadap niat Pembelian Ulang 
online sebesar 0,273. Sedangkan pada pengujian pengaruh tidak langsung besarnya pengaruh tidak langsung PeoU terhadap niat pembelian ulang online melalui sikap konsumen sebesar 0,128. Berdasarkan perbandingan dua hasil tersebut, dapat disimpulkan bahwa variabel intervening (sikap konsumen) kurang berperan karena nilainya lebih kecil dibanding dengan hasil pengujian pengaruh langsung.

c. Pengaruh Total Antar Variabel

Pengaruh total merupakan pengaruh yang disebabkan oleh adanya berbagai hubungan antar variabel baik langsung maupun tidak langsung. Ringkasan mengenai pengaruh langsung dari variabel tersebut dapat dilihat pada tabel 6 berikut.

Tabel 6. Pengaruh Total Antar Variabel

\begin{tabular}{|c|l|c|c|}
\hline \multirow{2}{*}{$\begin{array}{c}\text { Pengaruh } \\
\text { Langsung }\end{array}$} & \multicolumn{3}{|c|}{ Variabel Endogen } \\
\cline { 2 - 4 } & $\begin{array}{l}\text { Perceived Ease } \\
\text { of Use }\end{array}$ & Sikap Konsumen & Niat Pembelian Ulang \\
\cline { 2 - 4 } Variabel & $\begin{array}{l}\text { Perceived } \\
\text { Eksogen }\end{array}$ & 0,291 & 0,401 \\
\cline { 2 - 4 } & $\begin{array}{l}\text { Usefulness } \\
\text { Sikap }\end{array}$ & 0,000 & 0,218 \\
\hline
\end{tabular}

Sumber: Hasil Analisis

Berdasarkan tabel 6 tersebut dapat diketahui bahwa pengaruh total Perceived Ease of Use terhadap sikap konsumen sebesar 0,330 dengan arah positif, Perceived Usefulness terhadap sikap konsumen sebesar o,291 dengan arah positif, Perceived Ease of Use terhadap niat pembelian ulang online sebesar 0,401 dengan arah positif, Perceived Usefulness terhadap niat pembelian ulang online sebesar 0,218 dengan arah positif, dan sikap konsumen terhadap niat pembelian ulang online sebesar 0,388 dengan arah positif.

Berdasarkan pengujian tersebut dapat dinyatakan bahwa Perceived Ease of Use mempunyai efek total terbesar terhadap sikap konsumen dan niat pembelian ulang online.

Hasil pengujian pengaruh langsung pada tabel 4 menunjukkan bahwa besarnya pengaruh langsung PU terhadap Pembelian Ulang online sebesar 0,105. Sedangkan pada pengujian pengaruh tidak langsung besarnya pengaruh tidak langsung PU terhadap pembelian ulang online melalui sikap konsumen sebesar 0,113. Berdasarkan perbandingan dua 
hasil tersebut, dapat disimpulkan bahwa variabel intervening (sikap konsumen) sangat berperan karena nilainya lebih besar dibanding dengan hasil pengujian pengaruh langsung.

\section{PEMBAHASAN}

\subsection{Pengaruh Perceived Ease of Use terhadap Sikap Konsumen}

Perceived Ease of Use memiliki pengaruh terhadap sikap konsumen karena kemudahan penggunaan yang dirasakan dapat menimbulkan sikap positif pada konsumen. Dengan demikian semakin konsumen menganggap penggunaan suatu teknologi itu mudah, mudah dalam arti dipahami, mudah digunakan, jelas prosesnya, maka sikap mereka terhadap teknologi tersebut semakin positif.

Kemudahan penggunaan teknologi berpengaruh positif dan signifikan terhadap sikap atas online. Temuan penelitian ini medukung penelitian (Davis et al 1989; Moon and Kim, 2001; Chen et al., 2002; O'Cass and Fenech, 2002). yang menyatakan bahwa Perceived Ease of Use mempunyai pengaruh yang signifikan terhadap sikap konsumen. Hal ini menunjukkan bahwa Perceived Ease of Use dapat meninggkatkan sikap konsumen pada pembelian online.

\subsection{Pengaruh Perceived Usefulness terhadap Sikap Konsumen}

Perceived Usefulness memiliki pengaruh terhadap sikap konsumen karena manfaat yang dirasakan berpengaruh signifikan terhadap sikap konsumen, manfaat-manfaat yang dirasakan seperti pembelian online lebih efisien, cepat, hemat tenaga, hemat waktu, efektif, bisa dilakukan dimana saja dan kapan saja, tidak terhalang dengan jarak tempat pembeli dan penjual, hal tersebut akan berpengaruh positif terhadap sikap konsumen. Dengan demikian jika manfaat dari penggunaan teknologi online dirasakan tinggi maka sikap konsumen terhadap pembelian online menjadi positif.

Hal ini berarti jika faktor manfaat pembelian online yang dirasakan semakin baik atau meningkat, maka akan meningkatkan sikap konsumen pada pembelian online. Begitu pula sebaliknya jika dirasakan Perceived Usefulness turun maka dapat juga menurunkan sikap konsumen pada pembelian online.

\subsection{Pengaruh Perceived Ease of Use terhadap Niat Pembelian Ulang online}

Pengaruh manfaat yang dirasakan terhadap niat pembelian ulang online karena ada hubungan langsung yang kuat antara kemanfaatan dan niat. Hal ini menjelaskan bahwa konsumen berniat untuk menggunakan teknologi, karena teknologi tersebut bermanfaat bagi konsumen. 
Hal ini berarti jika faktor kemudahan penggunaan pembelian online yang dirasakan semakin baik atau meningkat, maka akan meningkatkan niat pembelian ulang online. Begitu pula sebaliknya jika Perceived Ease of Use menurun juga dapat menurunkan niat konsumen untuk melakukan pembelian ulang secara online. Temuan penelitian ini medukung pendapat Davis et al, (1989) yang menyatakan tentang hubungan langsung yang kuat antara kemanfaatan dan niat. Pernyataan ini menjelaskan bahwa konsumen berniat untuk menggunakan teknologi, karena teknologi tersebut bermanfaat bagi konsumen. Jika konsumen melakukan pembelian online bermanfaat dalam arti lebih efisien, hemat tenaga, lebih cepat, maka konsumen akan berniat untuk melakukan pembelian online.

\subsection{Pengaruh Perceived Usefulness terhadap Niat Pembelian Ulang online}

Hasil penelitian menunjukkan faktor Perceived Usefulness berpengaruh tidak signifikan terhadap niat pembelian ulang online. Hal ini berarti meskipun persepsi konsumen atas variabel Perceived Usefulness semakin baik atau meningkat, maka belum tentu akan diikuti oleh peningkatan niat pembelian ulang online. Dalam hal ini konsumen akan tetap menggunakan pembelian online jika sikap konsumen pada pembelian online sudah baik atau dapat dikatakan bahwa Perceived Usefulness berpengaruh secara tidak langsung terhadap niat pembelian ulang online melalui sikap konsumen pada pembelian online. Tetapi jika konsumen tidak puas dengan pembelian online yang mereka inginkan, maka akan berdampak menurunkan niat pembelian ulang online

Menurut TAM, kemudahan penggunaan yang dirasakan (PeoU) memiliki dua pengaruh, yaitu pengaruh langsung maupun tidak langsung pada niat konsumen untuk membeli. Pengaruh tidak langsung pada niat adalah, melalui manfaat yang dirasakan. Pengaruh langsung dijelaskan oleh fakta bahwa dalam perilaku pengambilan keputusan, konsumen berusaha meminimalkan upaya dalam perilakunya, dalam arti konsumen mencari proses yang paling mudah bagi mereka dalam pembelian, dengan kata lain semakin mudah proses penggunaan teknologi untuk pembelian online; prosesnya mudah dipahami, situs pembelian mudah ditemukan, prosedur jelas, maka konsumen akan semakin berniat untuk melakukan pembelian dengan cara online, dengan persepsi bahwa pembelian melalui online akan bebas dari kesulitan atau memudahkan (Davis et al.,1989; Venkatesh, 2000).

\subsection{Pengaruh Sikap Konsumen terhadap Niat Pembelian Ulang online}

Hasil penelitian menunjukkan sikap konsumen mempunyai pengaruh yang signifikan terhadap niat pembelian ulang online. Hal ini berarti jika sikap konsumen semakin baik atau meningkat, maka akan meningkatkan 
niat pembelian ulang online. Kardes (2002), menyatakan bahwa sikap merupakan konsep yang telah dikaji oleh banyak peneliti perilaku. Sikap dianggap sebagai faktor yang menentukan perilaku konsumen. Menurut Schiffman dan Kanuk (2007), dalam tataran praktis, semua aktivitas pemasaran berkaitan dengan sikap konsumen.

\section{KESIMPULAN}

Berdasarkan analisis yang telah dilakukan pada penelitian ini, maka dapat ditarik kesimpulan sebagai berikut:

a. Kemudahan penggunaan pembelian online yang dirasakan berpengaruh signifikan terhadap sikap konsumen pada pembelian online. Hal ini berarti jika faktor kemudahan penggunaan pembelian online yang dirasakan semakin baik atau meningkat, maka akan meningkatkan sikap konsumen pada pembelian online. Begitu pula sebaliknya jika Perceived Ease of Use yang dirasakan turun, maka juga menurunkan sikap konsumen pada pembelian online.

b. Manfaat pembelian online yang dirasakan berpengaruh signifikan terhadap sikap konsumen pada pembelian online. Hal ini berarti jika faktor manfaat pembelian online yang dirasakan semakin baik atau meningkat, maka akan meningkatkan sikap konsumen pada pembelian online. Begitu pula sebaliknya jika dirasakan Perceived Usefulness turun maka dapat juga menurunkan sikap konsumen pada pembelian online.

c. Kemudahan penggunaan pembelian online yang dirasakan berpengaruh signifikan terhadap niat pembelian ulang online. Hal ini berarti jika faktor kemudahan penggunaan pembelian online yang dirasakan semakin baik atau meningkat, maka akan meningkatkan niat pembelian ulang online. Begitu pula sebaliknya jika Perceived Ease of Use menurun juga dapat menurunkan niat konsumen untuk melakukan pembelian ulang secara online. Davis et al, (1989) berpendapat tentang hubungan langsung yang kuat antara kemanfaatan dan niat. Hal ini menjelaskan bahwa konsumen berniat untuk menggunakan teknologi, karena teknologi tersebut bermanfaat bagi mereka.

d. Manfaat pembelian online yang dirasakan berpengaruh tidak signifikan terhadap niat pembelian ulang online. Hal ini berarti meskipun persepsi konsumen atas Perceived Usefulness semakin baik atau meningkat, maka belum tentu akan diikuti oleh peningkatan niat pembelian ulang online. Menurut TAM, kemudahan penggunaan yang dirasakan (PeoU) memiliki dua pengaruh, yaitu pengaruh langsung maupun tidak langsung pada niat konsumen untuk membeli. Pengaruh tidak langsung pada niat adalah, melalui manfaat yang dirasakan. Pengaruh langsung dijelaskan oleh fakta bahwa dalam perilaku pengambilan keputusan, konsumen berusaha meminimalkan upaya dalam perilaku mereka, dalam 
arti konsumen mencari proses yang paling mudah bagi mereka dalam pembelian.

e. Sikap konsumen berpengaruh signifikan terhadap niat pembelian ulang online. Hal ini berarti jika sikap konsumen semakin baik atau meningkat, maka akan meningkatkan niat pembelian ulang.

\section{DAFTAR PUSTAKA}

Azjen, and Fishbein. 1975. Understanding Attitudes and Predicting Social Behavior. Prentice-Hall.Englewood Cliffs, N.J.

Childers, T.L., Carr, C.L., Peck, J. and Carson, S. 2001. "Hedonic and utilitarian motivations for online retail shopping behavior", Journal of Retailing, Vol. 77 No. 4, pp. 511-35

Chen, L., Gillenson, M.L. and Sherrell, D.L. 2002. "Enticing online consumers: an extended technology acceptance perspective", Information \&Management, Vol. 39 No. 8, pp. 705-19.

Davis, F.D. 1989. "Perceived usefulness, perceived ease of use, and user acceptance of information technology", MIS Quarterly, Vol. 13 No. 3, pp. 319-40. 1993."User acceptance of information technology:system characteristics, user perceptionsand behavioralimpacts", Internationa Journal of Man-Machine Studies, Vol. 38 No. 3, pp. 475-87.

Ferdinand, A. 2002.Structural Equation Modelling dalam Penelitian Manajemen, Aplikasi Model-Model Rumit dalam Penelitian untuk Tesis $S$-2 dan Penelitian $S$-3.Semarang. BP Universitas Diponegoro.

Gefen, D. 2003. TAM or Just Plain Habit: A Look at Experienced Online Shoppers. Journal of End User Computing. (Vol.15). No. 3: 1-13

Kardes, F. R. 2002. Consumer Behavior and Managerial Decision MakingSecond Edition. Upper Saddle River, New Jersey. Pearson Education, Inc.

Kotler, Philip \& Kevin Keller. 2012. Marketing Management 12e. New Jersey: Pearson Education.

Lederer, A.L., Maupin, D.J., Sena, M.P. and Zhuang, Y. (200o), "The technology acceptance model and the World Wide Web", Decision Support Systems, Vol. 29 No. 3, pp. 269-82.

Moon, J.-W.and Kim, Y.-G. 20o1. "Extending the TAM for a World-WideWeb context", Information \& Management, Vol. 38 No. 4, pp. 217-30.

Mowen, John C \& Minor, Michael. 2001. Consumer Behavior. $5^{\text {th }}$ edition.Harcourt, Inc.

O'Cass, A. and Fenech, T. 2002. "Web retailing adoption: exploring the nature of Internet users web retailing behavior", Journal of Retailing and Consumer Services, (forthcoming).

O'Brien, J. A. 2005. Introduction to Information Systems 12th Edition.McGraw-Hill 1221 Avenue of the Americas. NY. 10020 
Schiffman, Leon G. \& Leslie Lazar Kanuk. 2007. Consumer Behavior $9^{\text {th }}$ Ed. New Jersey: Pearson Education Inc.

Venkatesh, V. (2000), "Veterminants of perceived ease of use: integrating control, intrinsic motivation, and emotion into the technology acceptance model", Information Systems Research, Vol. 4 No. 4, pp. 34265. 